Bisserka Veleva

930.85

Sr.Asst.Prof., PhD,

Sofia University

https://doi.org/10.18485/climb.2017.5.1.ch17

"St. KI. Ohridski"

Bulgaria

Valentin Petroussenko

Assoc.Prof., PhD,

Plovdiv University "P. Hilendarski”

Bulgaria

\title{
LANGUAGE OF DIPLOMACY AS A SPECIFIC STRUCTURAL AREA OF KNOWLEDGE
}

\section{Summary}

The topic of this article is the modern diplomatic language, connected with the diplomatic correspondence as a main written medium for realizing the diplomatic relationships among the countries. The analysis is based on authentic documents from some recent years. The aim of this research is to underlie uniformity between function and form of the most official document in the area of diplomacy in Bulgaria - the diplomatic invitation. Its peculiarity consists in keeping very strict rules in the formation of the text part and in the selection of its distinctive elements such as format, color, etc. The research will be finalized by conclusions, which would put more light on the intact until now problems of the essence and significance of the diplomatic correspondence.

Key words: language of diplomacy, diplomatic correspondence (invitation), text linguistics, communication

\section{Introduction}

"Diplomacy is the means by which States throughout the world conduct their affairs in ways to ensure peaceful relations" (FDFA 2008: 3) and ac- 
cording the Oxford Learner's Dictionary ${ }^{1}$ diplomacy is "the management of relations between countries ... art of or skill in dealing with people; tact...".

Since the very beginning of the interstate relations, back in history, the language of diplomacy has been an important vehicle of communication. It is based on strict rules of diplomatic protocol and possess generally conservative structure. However the patterns of diplomatic communication aim to establish bridges among cultures and religions, therefore is of great importance the balanced presentation of cultural and spiritual traditions. Thus, our paper focuses on the use of the modern diplomatic language.

Important role in realization of international relations of each country plays the diplomatic correspondence. It is designed to reflect truly and correct, to keep (most often on paper), the entire international activity of the state and its institutions. The process of preserving of information, which keeps certain legal regulation, is known with the term documentation, and its product are the different kinds of diplomatic documents.

Undoubtedly, one of most representative diplomatic documents is the diplomatic invitation, which is in the center of this research. The choice of topic came from the fact, in the bibliography in Bulgaria and abroad, regarding the essence and characteristics of the diplomatic correspondence, mainly the problems of the content and form of diplomatic documents are studied (Kozhuharov 1999; Kurbalija and Slavic 2001; Borunkov 2005; Ivanova 2007; FDFA 2008; Romanov 2014; etc.), but there are no publications, which analyze the question of the color and general layout in the elaboration of this official document.

Purpose of this study is to present the specifics which appear when invitation is produced, with its characteristics as linguistic text and also to highlight the special role of the colors, because they play peculiar function, connected with the content and the rest of formal features of the document, such as typewrite, format, etc.

Through analysis of some authentic documents a task is given to show up the basic principles during the composition and the structure of the diplomatic invitation. The research is made based on the method of "document analysis" (Osipov 2006), known also as analysis of the document content (Mayring 2000) or "content analysis" (Berelson 1952; Stemmler 2001), also there is implied the Lasswell model for realization of successful communication, named as the "model of five Ws""2 (Lasswell 1948).

1 Oxford Learner's Dictionary, 4th ed., Oxford University Press. Oxford, 1994, p. 338.

2 Original in English "The 5 W's of Communication". 


\section{Diplomatic invitation - function, shape and color}

As it is in every other type of document in the field of diplomatic correspondence when diplomatic invitation is composed it is necessary to know and to keep some legal norms and rules, which are settled in advance $^{3}$. They have obligatory character, which derives from the very purpose of the invitation. In quality of "governmental or diplomatic act", which comprises "elements of correspondence", and in a form of "wishes", it is through this mean that some will towards inclusion to some event is expressed (Romanov 2014: 58-59). According to the diplomatic practice in Bulgaria and abroad with this document is announced the organization of:

a) Diplomatic Reception;

b) Solemn Event;

c) Business Meeting.

The initiative, organization and performance of such events is made by foreign embassies or missions in another country. That is why such huge responsibility upon respective institutions during its preparation derives.

This research focuses on the first type of invitation - for attendance on a diplomatic reception or cocktail, celebrating the Nationbal Day of given country, from which side the Embassy is sending the invitation.

\subsection{Diplomatic invitation to Diplomatic Reception - examples}

In this paper some samples of original documents are presented in an alphabetical order, these are official invitations to diplomatic receptions, and they demonstarate the essence of these peculiarities. At the same time they represent different variations of the act of communication in a written form.

3 The order to compose diplomatic documents is regulated by the Law for the State Protocol and by the Statute fot its application as well as by the traditions and norms of the Diplomatic Jurisprudence in Bulgaria. 
Example 1: Invitation from the Embassy of Republic of Austria (2017)

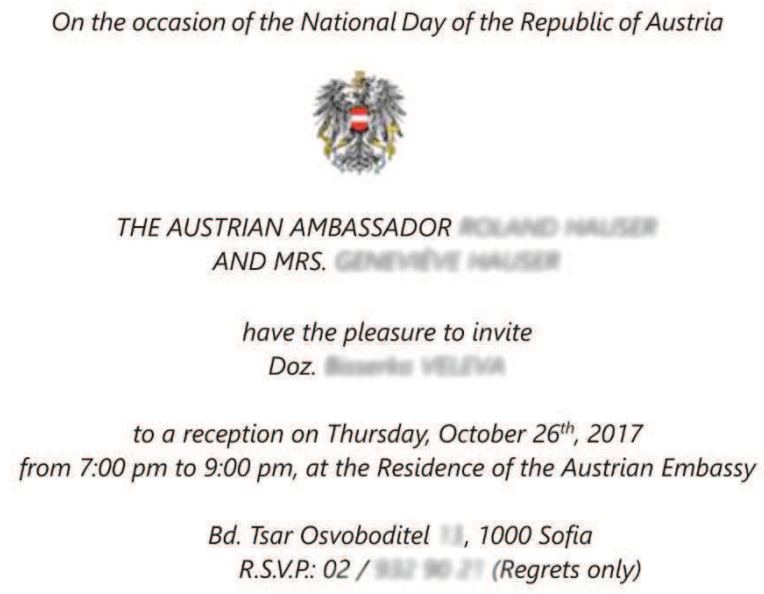

THE AUSTRIAN AMBASSADOR NOU No NaUsin

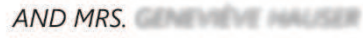

have the pleasure to invite Doz. llwester viturnat

to a reception on Thursday, October $26^{\text {th }}, 2017$ from 7:00 pm to 9:00 pm, at the Residence of the Austrian Embassy

Bd. Tsar Osvoboditel 11, 1000 Sofia

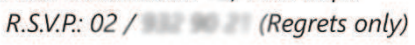

Please, present this invitation at the entrance.

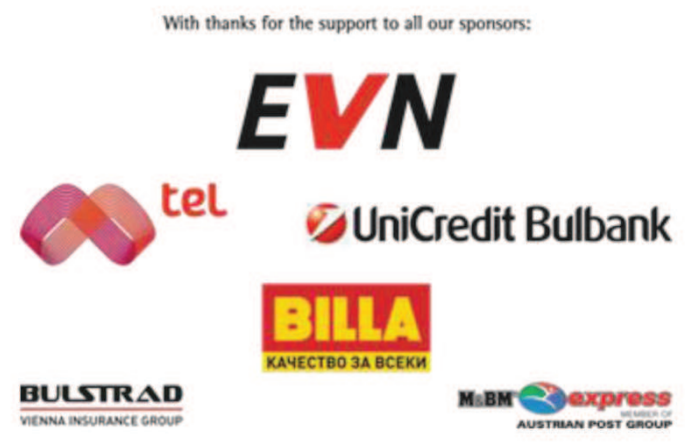

Example 2: Invitation of the Embassy of the People's Democratic Republic of Algeria (2017)

On the occasion of the $\mathcal{N}$ ational Day, the $1^{\text {st }} \mathcal{N}$ November 1954

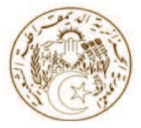

Her Excellency the Ambassador of Algeria and $\mathcal{M r}$.

request the pleasure of the company of

Mrs. and spouse to a reception

on Friday, $3^{\text {rd }}$ November 2017 from 18.30 to 20.30 Sofia

Phone:

(Regrets only) 
Example 3: Invitation from the Embassy of Kingdom of Spain (2017)

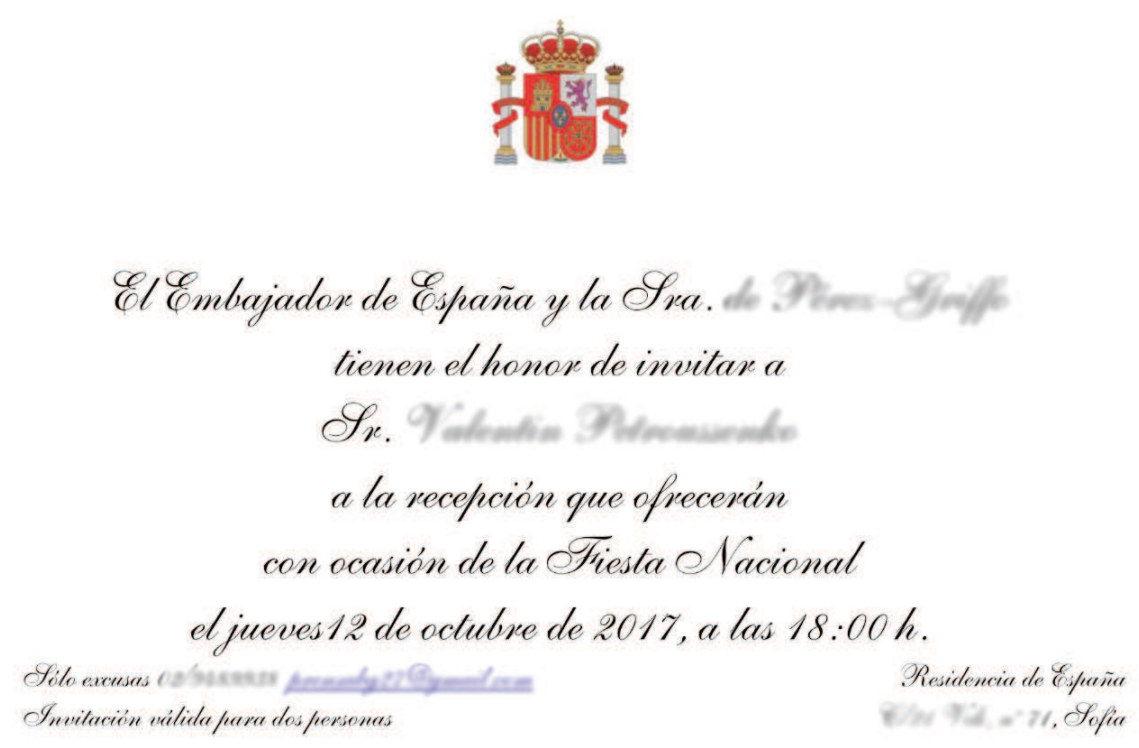

Example 4: Invitation from the Embassy of Lebanese Republic (2013)

Marking the 70th Anniversary of thelndependence of Lebanon and the 30thAnniversary of the Embassy in Sofia

The Ambassador of Lebanon and Mrs. Nariman Baydoun Eid

have the honor to invite

Mrs.

at a reception on Friday, November 22nd 2013, at 19.00-21.00hrs

Sredetz Ballroom

Sheraton Sofia Hotel Balkan
Regrets only

$02 / \ldots \ldots \ldots . . . . . .$. 
Example 5: Invitation from the Embassy of Kingdom of Morocco (2016)

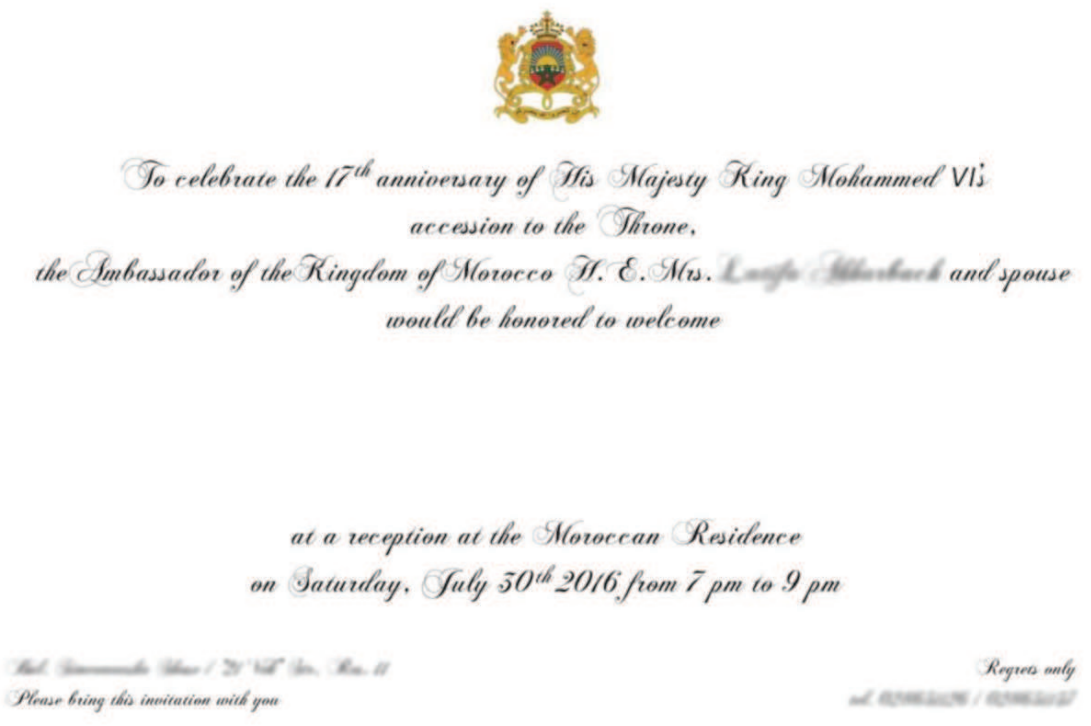

Example 6: Invitation from the Embassy of Republic of Turkey (2017)

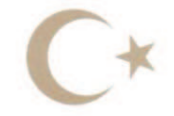

On the occasion of the $93^{\text {rd }}$ Anniversary

of the proclamation of the Republic of Turkey,

The Ambassador of Turkey and $\mathcal{M r s}$.

request the pleasure of the company of

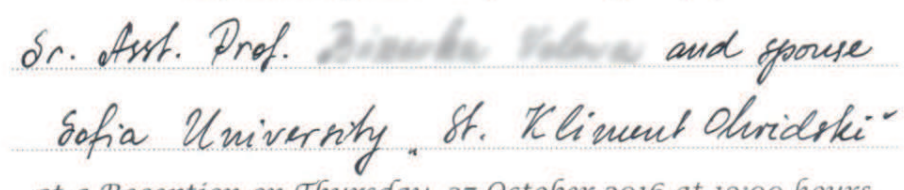

at a Reception on Thursday, 27 October 2016 at 19:00 hours.

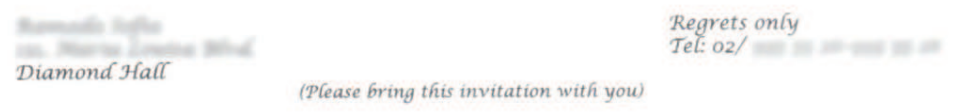




\section{Култура и/или наука}

Example 7: Invitation from the Embassy of French Republic (2016)

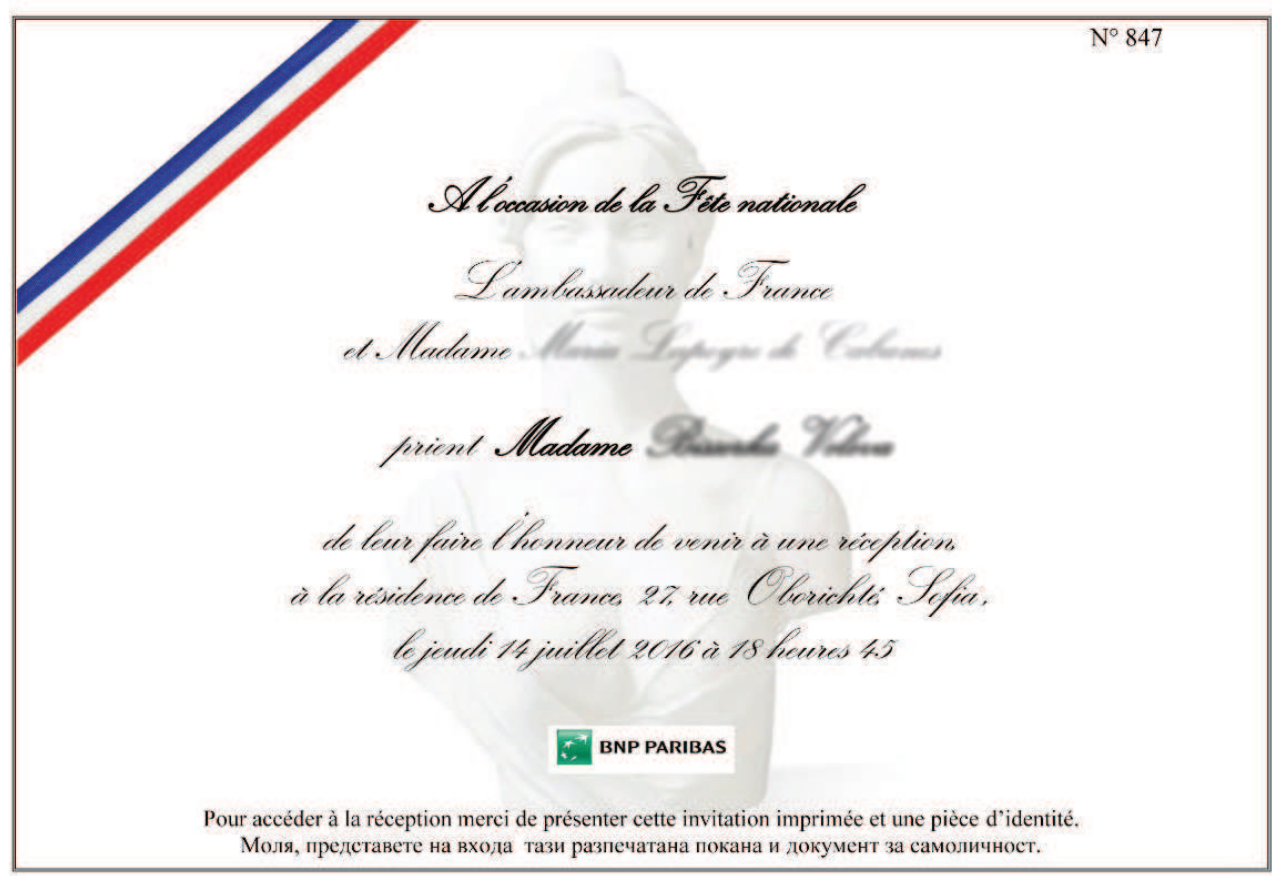

2.2. Diplomatic invitation to Diplomatic Reception - analysis

The official type of event, under which the invitation is issued, defines the peculiar characteristics of the document in regards of:

a) Linguistic text; b) Typography product; c) Presence of colors.

The combination of the three elements comprises the unity of content, form and color, each of them having equal as significance functions.

In the arrangement of information of the invitation applies very strict jerarchical order, most often it visually takes the shape of pyramid, or a structure, which appear as a sand clock, in which on the upper part of the sheet is placed the information segment with highest rank. The text and the symbols are presented in the center of the invitation. The sequence of the segments on the invitation and the list of lines from up to below are strictly observed:

- 1st line $\rightarrow$ empty (all invitations, except France ${ }^{4}$ ), the tricolor encompasses the upper left angle (France), and on the upper right angle is fixed the number of the invitation;

- 2nd line $\rightarrow$ empty;

For shorter mode in the text, only the name of the state, issuing the invitation will be used. 
- 3rd line $\rightarrow$ occasion of the event - National Day (Austria, France), anniversary of the intronization of the king (Morocco), there may appear the initial date. Month and the year of the event (Algeria) or as marking the exact anniversary (Turkey);

- 4th line $\rightarrow$ official symbol of the state - coat of arms (Austria), insignia (Algeria,

Turkey), tricolor (France) and similar.

- 3rd and 4th line are replaced- the coat of arms stays above all (Spain, Morocco, Turkey).

- 5th line $\rightarrow$ the title of ambassador and the name of the state, which he represents (if the ambassador is male, his title is e His Excellency; if female - Her Excellency (Algeria, Morocco), sometimes appear the ambassador's name with title and invocation (Morocco) or only the name of ambassador and the state (Austria, Spain, Turkey);

- 6th line $\rightarrow$ the name of the spouse of ambassador, after which follows his/her family name;

- 7th line $\rightarrow$ the request of the на inviting, e,g. the ambassador;

- 8th line $\rightarrow$ the address towards the invitee, after which follows the name and surname of the invitee and his/her spouse;

- 9th line $\rightarrow$ occasion of the invitation;

- 10th line $\rightarrow$ day of the week, month and year of the reception, with expressly clarification of the initial and end time of the event with minutes;

- 11th line $\rightarrow$ premises, where the event will happen, as well as the telephone number for confirmation or rejection of the invitation;

- 12th line $\rightarrow$ the hall in the building, where the event will be celebrated, as well as the request to invitee to let know the inviting by telephone, whether he/her can't attend the invitation;

- 13th line $\rightarrow$ empty.

The analysis of the documents is made within the frames of the "model of five Ws", known also as "Lasswell's model of communication", or "Lasswell's communication model", an approach elaborated by Lasswell (Lasswell 1948: 117). The concept of this model consists in that, the act of communication is presented as a compound of activities, each of them can be described and analysed, if there has been layed an answer to the five questions beginning with "W": 
(1) Who is communicating, shows the author or the source, which

(2) says What, which represents the message

(3) in what Way or through Which channel or media

(4) to Whom, which means receiver or audience and

(5) with What or Which effect or feedback, result, impact (Lasswell 1948: 117).

According to Lasswell's theory in the examined documents the role of "Who"

implements the foreign embassies, with the ambassadors at the head of the indicated countries, чрез "What" is expressed the desire to issue invitation, and the selected "Way" or "Which" channel or media is the official document, that is sent either by post in envelope (when it is on paper carrier), or electronically, when is sent by e-mail, "Whom" or receiver is the person, to whom the invitation has been sent, while with "What" or "Which" effect or feedback, result, impact is implied the influence of the invitation on the addressee with the aim to activate his/her reaction to follow or not to follow the invitation issued to him/her.

Substantially this scheme does not differ in its essence from the text linguistics perception of this official document as a type of text: the text is created by Producent (the person who is speaking or writing), in this case as a written form, with exactly formulated goal towards exactly specified $R e-$ cipient (listener or reader), the text is product with specific linguistic and social nature, and it distinguishes from so called Textuality. R.-A. de Beaugrande and W. U. Dressler (De Beaugrande and Dressler 1981) define the text as a "communicative occurrence which meets seven standards of textuality" - Cohesion, Coherence, Intentionality, Acceptability, Informativity, Situationality and Intertextuality, without any of which the text will not be communicative. Non-communicative texts are treated as non-texts.

It is acknowledged, that the texts in semantic treatment are more than the sum of their parts, and this is formulated in linguistics on different way (Fix 2007: 323 and 330; Katz 1948: 51f.; Luhmann 1984; etc.).

For Brinker the function of text consists in invested by author intention to realize communication through certain common means. In this direction of thinking he distinguishes five main functions of the text: informative, appellate, compulsory, contact and declarative (Brinker 2000: 175; Kileva-Stamenova 2011: 28). Assignation of concrete text is made with the help of so called identifiers: 
a) intratextual, ("innertextliche"), most of them are linguistic and

b) outertextual "außertextliche" or "konextuelle" means (Brinker 2000: 90).

Towards the concept of textual are referred linguistic vehicles as morphological, syntax or similar, for example "modus", types of sentences, certain adverbs, etc. Towards this type of indicators are assigned also nonlinguistic means such as - graphic design and illustrations (Brinker 2000: 180). According the classification of Brinker about the kinds of text, presented in this article sample of text is from the second type as appellate, because the intention of the author of the official invitation is to call the recipient towards action, and the result would be his/her attendance of the official event. Marked by Brinker as linguistic and non-linguistic means (graphic design and illustrations), corresponds to the considered in this paper as a) Linguistic text; b) Typography product; c) Presence of colors.

Some of typical to this kind of text linguistic vehicles or phrases, which are composite part of the text for this kind of invitation, and they are:

- the ambassador of

- on the occasion of the National Day of

- would be honored or would be honored to invite or have the pleasure to invite or request the pleasure of the company of

- at (to) a reception at (place) on (day).

Some invitations have on the one of two last lines the abbreviation R.S.V.P. It has been adopted in the dipolmatic documentation from French language - "Repondez, s'il vous plait", which means "Please, respond". These initials are interpreted as a request towards the person, which has received the invitation, to give obligatory answer whether the invitation will be accepted or not, and this should happen within 48 hours after receiving it (Romanov 2014: 58-59).

However, the practice shows that this happens very seldom. The other option might be, when on the same place the mark is in English and reads "Regrets only", or most often in French "En cas d'empechement". In this case the invitee is not obliged to respond if he/she decides to take the invitation, but he/she must inform the embassy, on the above mentioned circumstance this invitation will not be used (Romanov 2014: 5859). It is possible on the same section of the page are another instructions: (Please,) Bring the invitation with you (Morocco, Turkey), "Please, present this invitation at the entrance" (Austria), sometimes there is also 
request to present ID card or passport (France) or "Invitaciỏn válida para dos personas", in translation "The invitation is valid for two persons", added by "With thanks for the support to all our sponsors:" (Austria), or contribution of sponsors only by the logo of the brand (France).

Regarding the text as a typographic product it may be noted, that except the above mentioned and usually accepted common positioning of the text onto the sheet of paper, is established, that the text layout is being set with different typefaces chosen by the typesetters:

- sans serif italic type - Segoe UI (Austria);

- chancery writing (typeface) - Monotype Corsiva (Algeria);

- chancery writing (typeface) (Turkey);

- round hand - English style - Kunstler Script (Spain, Morocco, France);

- cursive type - Mistral (Lebanon).

Where the font sizes vary between 18-30 points, depending on the typeface's specifics.

The paper size of the invitations in the most cases is $A 6$ (like the size of post cards) ${ }^{5}$. The text is being printed or rarely is being handwritten over paper that like the postcards. The text is usually printed or, more rarely, is handwritten, onto thin cardboard, which like a postcard may be placed into a standard envelope, and afterwards is sent by post service or by courier. During the last years it becomes wholly acceptable that the invitations are scanned and sent by electronic means. The addressee has the obligation to print the invitation and to present it upon the entrance of the hall where the diplomatic reception is conducted. It is not accepted that the invitation is bended.

The cardboard or sheet of paper, onto which the invitations are shaped usually are in neutral color or white, the text always is made in black, in printed font, which may vary, but should be enough large, that the text may be red easily and fast. On the neutral main background state symbols stand out, they may be coat of arms, emblems, cut offs of national flags, etc. It is acceptable certain styling of the coats of arms and the emblems, such is the case of the rich in colorful depictions invitation

5 Size of the paper sheet. According the metric system of size (format) of the paper sheet, adopted by the International Organization for Standardization (ISO). Available: https:// bg.wikipedia.org/wiki/\%D0\%A0\%D0\%B0\%D0\%B7\%D0\%BC\%D0\%B5\%D1\%80\%D0\%B8_\% D0\%BD\%D0\%B0_\%D1\%85\%D0\%B0\%D1\%80\%D1\%82\%D0\%B8\%D1\%8F\%D1\%82\%D0\%B0 (01.12.2017). 


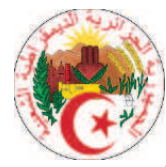

represented in golden brown color

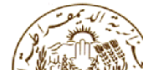

\section{a.} not affect the elegance shape of the invitation and the colorful original emblem on it. Same effect may be observed on the invitatrion of Turkey, where the red non official emblem is also depicted in golden brown color.

Which is the overall repercussion of the colors? When the colors included to the depiction of the coat of arms and the emblem are not styled, and preserve their authentic colouring, they turn into central part of the document and immediately attract the attention of the recipient. In the French Embassy invitation may be seen another two interesting points. Through the blue-white-red tricolor cut off, attached to the upper left angle, it acquires peculiar elegance. Another feature is the implied into grey gamut silhouette of силует of gentle femenine figure, which symbolizes the revolutionary spirit of the French people and its struggle for democratic republic, reflected in the slogan "Liberty, equality and brotherhood".

The emblems and logos of the sponsors, who support the organization of the reception, are kept in their original colors. It is also very solemnly touch on the invitations when the salutation and names of the guest are handwritten with blue ink, as it is rule in Bulgaria and abroad to sign on any official diplomatic or internationally legal document.

\section{Conclusion}

The diplomatic invitation is international legal document with following features:

A) Linguistic text:

- predominant use of English, seldom Spanish or French;

- brevity and laconicity when choosing language expressions;

- use of international terms and abbreviations;

- formality, objectivity, standartisation, preciseness and correctness, rationality and politeness of the style.

B) Typographic product: 
- presence of attributes and symbols of the state power, as state coat of arms, emblem, national flag, etc;

- diversity of fonts and adherence to other typographic conditionalities;

- strict requirements towards the form of paper carrier for the layout of the document.

C) Colorful depiction:

- preciseness in selection of different colors and their nuances for the layout of the document;

- accurate requirements towards the colors with direct and symbolic significance.

This research finalizes with a conclusion, that creation of an official invitation for reception is a result of acquired diplomatic experience of different people, but also is based on the linguistic expertise, and the technical capabilities of the printing typography and the knowledge of the colors ' nature. Today these rules and traditions are expressed as a feature of multiculturalism and play very important role for the inclusion of people from variety of countries and cultures.

Presented analysis and the formulated generalizations and conclusions may contribute on theoretical and practical set of questions, connected with the essence and application of the diplomatic correspondence.

\section{References}

Book 1 author:

Berelson, B. (1952). Content Analysis in Communication Research. Glencoe, III: Free Press. Borunkov, A. F.(2005). Diplomaticheskijprotocolv Rossii.3 Ed. Moskva: "Mezhdunarodnaje otnoshenija".

Ivanova, D. (2007). Kultura na delovoto obshtuvane. Delova korespondentsija (Uchebno pomagalo za smopodgotovka). Plovdiv: Izdatelstvo IMN.

Katz, D. (1948). Gestaltpsychologie. 2 Ed. Basel: Benno Schwabe.

Kileva-Stamenova, R. (2011). Die Übersetzung öffentlicher Urkunden im Sprachenpaar

Bulgarisch und Deutsch. Sofia: Universitätsverlag „St. Kliment Ohridski“.

Kozhuharov, J. (1999). Diplomatsija i protocol. Sofia: Knigoizdatelska kashta „Trud“.

Luhmann, N. (1984): Soziale Systeme. Grundriß einer allgemeinen Theorie. Frankfurt a. M.: Suhrkamp.

OPRBE. (2012). Ofitsialen pravopisen rechnik na balgarskija ezik. Sofia: BAN, Prosveta. 84. (96.2), 88 (99.2), 100 (109.2).

Osipov, G.V. (2006). Rabochaja kniga soziologa. 4 Ed. Moskva: Nauka. 
PPZDP. Pravilnik za prilagane na zakona za darzhavnija protocol. PMS No. 172 (10 July 2009), DV No. 57 (24 July 2009), DV No. 27 (5 April 2016).

ZDP (2015). Zakon za darzhavnija protocol. DV No. 32 (18 April 2000), DV No. 35 (12 May 2009), DV No. 39 (26 May 2009), DV No. 61 (11 August 2015).

Book 2 or more authors:

De Beaugrande, R.-A. \& Dressler, W. U. (1981). Introduction to text linguistics. London; New York: Longman.

Kurbalija, J. \& Slavic, H. (2001). Language and Diplomacy. Mediterranean Academy of Diplomatic Studies. Malta: Academic Training Institute.

Lasswell, H. (1948). Bryson, L., Ed. The Structure and Function of Communication in Society. The Communication of Ideas. New York: Institute for Religious and Social Studies.

Romanov, D. Ed. (2014). Diplomaticheska entsiklopedija: Tseremonial, korespondentsija, biznes etiket. Plovdiv: Univ. Izdatelstvo "P. Hilendarski”.

Book Chapter:

Brinker, K. (2000). Textfunktionale Analyse. In: Brinker, K. \& ea. (Ed.) (2000). Text- und Gesprächslinguistik (Linguistics of Text and Conversation). Halbband 1 (HSK 16.1.), Berlin, New York, 175-187.

Fix, U. (2007): Zugänge zu Textwelten. Linguistisch-literaturwissenschaftliche Möglichkeiten, in die Geschlossenheit eines Erzähltextes einzudringen. In: Hermanns, Fritz/Holly, Wer-Ner (Ed.): Linguistische Hermeneutik. Theorie und Praxis des Verstehens und Interpretie-rens. Tübingen: Niemeyer. 323-356.

Veleva, B. Forma i tsvjat pri diplomaticheskata pokana. In: Balkankolor 2017 "Tsvjat vav vsichki napravlenija". Sofia: Color Group Bulgaria. 74-85.

Electronic source:

FDFA (2008). ABC of Diplomacy. Swiss Federal Department of Foreign Affairs. Bern: Swiss

FDFA. Available: https://www.eda.admin.ch/dam/eda/en/documents/publications/GlossarezurAussenpolitik/ABC-Diplomatie_en.pdf (26.11.2017).

Mayring, P. (2000). Qualitative Inhaltsanalyse [28 Absätze]. Forum Qualitative Sozialforschung / Forum: Qualitative Social Research [On-line Journal], 1(2). Available: http://qualitativeresearch.net/fqs/fqs-d/2-00inhalt-d.htm (28.11.2017). Copyright (C) 2000 FQS Available: http://qualitative-research.net/fqs (28.11.2017).

PS. Paper size. Available:

https://bg.wikipedia.org/wiki/\%D0\%A0\%D0\%B0\%D0\%B7\%D0\%BC\%D0\%B5\%D1\%80\%D0\%B8_\% D0\%BD\%D0\%B0_\%D1\%85\%D0\%B0\%D1\%80\%D1\%82\%D0\%B8\%D1\%8F\%D1\%82\%D0\%B0 (01.12.2017).

Stemler, S. (2001). An overview of content analysis. Practical Assessment, Research

\& Evaluation, 7(17). Available: http://PAREonline.net/getvn.asp?v=7\&n=17 (28.11.2017).

UNCM (2000). United Nations Correspondence Manual. A guide to the drafting, processing and dispatch of official United Nations communications. New York: United Nations. Available: http://archive.unu.edu/hq/library/resource/UN-correspondence-manual.pdf (29.11.2017). 


\section{Валентин Петрусенко \\ Бисерка Велева}

\section{ЕЗИКЪТ НА ДИПЛОМАЦИЯТА КАТО СПЕЦИФИЧНА СТРУКТУРНА ОБЛАСТ НА ПОЗНАНИЕТО}

\section{Сажетак}

В съвременния социален и политически живот все повече нараства значението на познанието. Нещо повече, познанието е изключително необходимо за да притежаваме необходимите способности за правилната комуникация. Ето защо езикът на дипломацията се е превърнал във фактор от ключево значение за разрешаване растящото международно напрежение, когато сме в условията на всеобхващащ конфликт. Езикът на дипломацията е също така важен за решението на вътрешнополитическите поблеми и създава мостовете за човешкото общуване, тъй като, и преди всичко, сме човешки същества.

Този доклад е продукт на сътрудничеството на специалист лингвист и историк, като и двамата са посветили голяма част от изследванията си на проучването на международните отношения. Затова целта на настоящата работа е да се посатви нов подход към анализа на езика на дипломацията като средство за комуникация и като специфичен елемент в структурната област на познанието на модерното общество.

Кључне речи: Ключови думи: лингвистика, история, дипломация, международни отношения. 